\title{
Influences of Building Characteristics and Attitudes on Water Conservation Behavior of Rural Residents
}

\author{
Yan Liu ${ }^{1}$, Yan Wang ${ }^{2, *}$, Han Zhao ${ }^{3}$, Yibin Ao ${ }^{4}$ and Linchuan Yang ${ }^{5}$ (D) \\ 1 School of Public Affairs and Administration, University of Electronic Science and Technology of China, \\ Chengdu 611731, China; liuyan7720@uestc.edu.cn \\ 2 Department of Engineering Management, Sichuan College of Architectural Technology, \\ Deyang 618000, China \\ 3 China Southwest Geotechnical Investigation \& Design Institute Co. Ltd., Chengdu 610051, China; \\ zhao.hubery@outlook.com \\ 4 College of Environment and Civil Engineering, Chengdu University of Technology, Chengdu 610059, China; \\ aoyibin10@mail.cdut.edu.cn \\ 5 School of Architecture and Design, Southwest Jiaotong University, Chengdu 611756, China; \\ yanglc0125@swjtu.edu.cn \\ * Correspondence: wangyan_hy09@sina.com
}

Received: 31 July 2020; Accepted: 10 September 2020; Published: 16 September 2020

check for updates

\begin{abstract}
Urbanization promotes the development of human civilization but brings great challenges, such as air pollution, lack of water resources, and environmental damage, to the natural environment. Water conservation effectively alleviates the lack of water resources. Existing studies mostly focus on water conservation behavior in urban areas and overlook rural areas. This study takes rural residents in Chengdu as the research object and selects four villages to conduct empirical research and fill this research gap. A total of 165 valid questionnaires are collected after face-to-face interviews. First, descriptive analysis is used to analyze the current situation of rural residents' water conservation behavior. Second, exploratory factor analysis and the binary logistic regression model are used to explore the relationship between building characteristics, water conservation attitudes, and water conservation behavior. The results show that (1) the rural residents' water conservation attitude plays an important role in water conservation behavior; "environmental values" is the most significant factor, followed by "saving money and joint participation;" (2) rural building characteristics such as layout of the kitchen and shower facilities significantly affect the water conservation behavior of rural residents. Based on the analysis, several suggestions are made for building a new water-saving rural area in Chengdu, such as strengthening the publicity and education of water-saving behavior and subsidizing water-saving facilities. This research provides a theoretical basis for local government departments to formulate relevant policies and serves as a valuable reference for the protection of water resources in other rural areas.
\end{abstract}

Keywords: building characteristic; water conservation behavior; water conservation attitude; binary logistic regression model; Sichuan; China

\section{Introduction}

Water resource plays an important role in people's life [1]. However, the global water crisis is increasing daily with rapid urbanization and a growing population [2,3]. China is one of the countries with the poorest per capita water resources in the world. The per capita water resource was only $1971.8 \mathrm{~m}^{3}$ in 2018 [4], accounting for one-fourth of the world average [5]. Water pollution, water scarcity, and flooding are the top three water resource challenges in China [6]. Groundwater is overdrawn by 10 billion cubic meters annually, but water supply always cannot meet demand [7]. The lack of 
water resources has seriously affected people's life not only in the urban area, but also in the rural area. For instance, more than 300 million residents in rural China have no access to safe drinking water [8]. Thus, research on the water shortage problem in rural China is of great significance.

Water conservation efficiently alleviates the challenges of water shortage $[9,10]$. This issue has gained much interest from practitioners and academia. There are various determinants affecting water conservation behavior. Several researchers argue that socio-demographic factors help predict water conservation behavior [11]. Some studies suggest that economic incentives, such as price control, are effective in encouraging the saving of water [12]. Several others propose that psychological characteristics, such as attitude, are critical determinants of water conservation [13,14].

Many studies believe that degree of urbanization will affect the water conservation behavior of residents [15,16]. Existing research focuses more on developed urban areas and less on rural areas [17]. In the past decades, the Chinese government built many infrastructures in rural areas, such as roads, hospitals, schools, and sewage treatment plants, which have greatly improved the living standards of rural residents. Moreover, the demand for water resources in rural areas is growing. China's rural areas face several challenges, such as lack of water conservancy infrastructure, huge gap in the water quality between urban and rural areas, and scarce water supply [18]. Therefore, it is imperative to investigate the water conservation behavior of rural residents.

Therefore, this study takes rural residents in Chengdu, China, as the research object and investigates the influence of various determinants on water conservation behavior using exploratory factor analysis (EFA) and binary logistic regression. Based on the results, several policy suggestions are made on the planning, construction, and management of rural water resources in Chengdu, which can also be promoted to other regional governments.

The rest of the study is organized as follows. Section 2 reviews related studies. Section 3 introduces the research design and data collection. Section 4 describes the empirical analysis results and discussion. Section 5 concludes the paper.

\section{Literature Review}

The water conservation behavior of residents is complex and mainly affected by socio-demographical factors, water conservation attitudes, and building characteristics.

\subsection{Socio-Demographic Factors}

Related research shows that the socio-demographic characteristics of family and individual can significantly affect domestic water consumption. The influencing factors include income, age, belief, gender, family population size, etc.

Many scholars have studied the relationship between household income and water consumption. The results show that the higher the income, the higher the water consumption $[19,20]$. High-income families often have more water equipment, such as dishwashers, washing machines, swimming pools, and outdoor garden watering facilities, than low-income families [21]. Their daily water demand is much greater than that of the low-income cohort. Fan believes that high-income groups have a greater capacity to pay, and their water fees only account for a small part of their total income. Thus, they are not sensitive to the regulation and control of water prices and are more likely to waste water resources [22].

Social variables such as age, household component, and education affect water usage as well. Foreign studies have found that the water consumption of families with numerous teenagers is generally on the high side, which is mainly because the water consumption of teenagers to pursue more comfortable living habits is much greater than that of older adults [23]. Studies in China also show that older adults are usually willing to take more active measures to save water mainly because they have a stronger sense of saving than the young [24]. The water consumption of residents of different races or faiths is also quite different [25], and that of collectivist families is relatively lower than that of other families [26]. Females are the main users of domestic water; thus, their behavior 
largely represents that of the whole family. As the manager or maintainer of the family, women often use more water than men. They usually take more active measures to save water [27]. Numerous studies show that the greater the number of permanent residents, the lower the per capita water consumption [28]. Chen and $\mathrm{Xu}$ [29] also proposed that the total household water consumption and the proportion of the educated family population have a significant correlation.

\subsection{Water Conservation Attitudes}

People's attitudes also affect people's behavior [30,31]. Over the years, many researchers attempt to understand the rationale of the behavior from the fundamental psychology. Theory of planned behavior [32] has been a leading model. This theory describes that an "individual makes behavioral decisions based on rational considerations," which implies that human behavior is a complex result of behavioral intention, attitude, and self-efficacy [33]. Attitude, which is defined as "strengths of beliefs about consequences of behaviors and evaluations of such consequences" [34], plays an important role in determining people's behavior [31,35]. Different environmental consciousness or water-saving attitudes will lead to different water-use behaviors $[36,37]$. Generally, the stronger the environmental awareness, the lower the water consumption. Household water consumption is higher with an insufficient or incorrect understanding of environmental awareness [38]. Based on 728 questionnaires collected in Bulgaria, Clark and Finley [39] testified that awareness of future water shortage and a positive environmental attitude have a significant influence on water conservation behavior. Willis and Stewart [40] found a significantly positive relationship between general environmental attitudes and water conservation behavior through field experiments and questionnaire surveys in Australia.

Previous research argues that pricing control is an efficient way to motivate water conservation behavior, that is, multi-tier pricing mode. Multi-tier pricing divides the water consumption of residents into several levels, and different water prices are set in each stage [41]. Average water prices increase with the progression of the stage. Increasing water price has been widely proven effective in reducing domestic water consumption [42]. However, more current research has found that water attitude is much more influential than price control. $\mathrm{Hu}$ [43] pointed out that the effect of water-saving publicity is more evident than that of water price on water-saving behavior. Mu and Zhang [44] found that compared with price regulation, residents' water-saving awareness plays a more important role in water-saving behavior based on survey data of 5000 Beijing residents in 2010. Chang [45] proposed that people could be led to save water through publicity and education, for example, using radio, banners, posters, or flyers. Related research shows that water conservation attitudes are vital to water conservation behavior.

\subsection{Building Characteristics}

Characteristics of housing, such as age, density, size, location, and the number of taps, have a great effect on water consumption. Generally, the larger the house, the greater the amount of water that will be used. Studies have shown that low-density buildings tend to use more water than high-density ones because they have more landscaping [46]. Kumar Chaudhary pointed out that water conservation is related to the residents' perception of landscape/outdoor benefits. The more beneficial their view, the higher the possibility that they will adopt water conservation behavior [47]. Huang and Huang investigated several communities in Shanghai by principal component analysis and found a significant difference between house price and house age on water consumption [48]. The water consumption of ordinary or low-price communities is significantly lower than that of high-price communities.

In summary, precious, scarce water resource has attracted many scholars to focus on the research of water conservation behavior, but a few research gaps remain: (1) Most of the existing research focus on developed areas, lacking attention to developing counterparts. The economic development level and residents' awareness of water conservation are dissimilar, which need to be differentiated. (2) Domestic scholars' research on water resource conservation and utilization mostly focuses on 
urban areas. Research is difficult, and the literature on rural areas is relatively limited due to the scattered residents. (3) Existing research mainly focuses on residential water consumption and the domestic water quota of urban residents [20,49]. Their focus is more on economic incentives, regulations, and socio-demographic characteristics. Therefore, this study aims to explore the influences of building characteristics and water-saving attitude on water conservation behavior after controlling the socio-demographic variables and provide theoretical implications for constructing sustainable rural areas.

\section{Research Design and Data Collection}

\subsection{Sample Village Selection}

The subjects of this study are rural residents in Chengdu, China. Chengdu is one of the pilot areas of urban-rural integration in China and has a wide range of rural areas, with 52 towns and 2658 villages. After conducting the pilot survey, the final selected typical sample villages should meet two conditions:

1. The villages need to be connected with tap water because this research studies the water-saving behavior of residents, which is measured using water-saving appliances (water-saving faucets, water-saving toilets, and water-saving washing machines). Such water-saving appliances need to be used with tap water.

2. The research team has good communication with the selected typical sample villages. Carrying out household interviews and comprehensive questionnaire surveys in rural areas is difficult, and the attitude of village cadres and the trust of villagers are important. Therefore, a good communication channel with the local community must be established. The research team solves this problem as follows: (1) At least one undergraduate student originally from the sample village must be willing to participate in the survey and act as the contact person. (2) The village cadres are contacted in advance; they accept and are willing to support the research group for the on-site survey. (3) Villagers' attitude toward the household questionnaire survey must be determined, and the village will be selected if most households welcome the research group.

Based on the above principles and preliminary selection, four villages around Chengdu were finally selected as the sample villages. These villages are Jin Ning Village in Pidu District, Tian Du Village in Xinjin County, Wu Xing community in Pujiang County, and Hua Guo Village in Longquanyi District. The specific geographical location is shown in Figure 1.

The selected villages are all new villages built in recent years. The specific investigation area of each village was limited within a circle of $1 \mathrm{~km}$ from the village center due to the complex topography of rural areas and the large difference in size, as shown in Figure 2. The original map was downloaded from the Qiaofeng map, and ArcGIS 10.2 was used to depict the land for buildings. In Figure 2, the village center is set as the center of the circle, and the research area is within a $1 \mathrm{~km}$ radius. The solid black line is the village road, and the pink area is the construction land. 


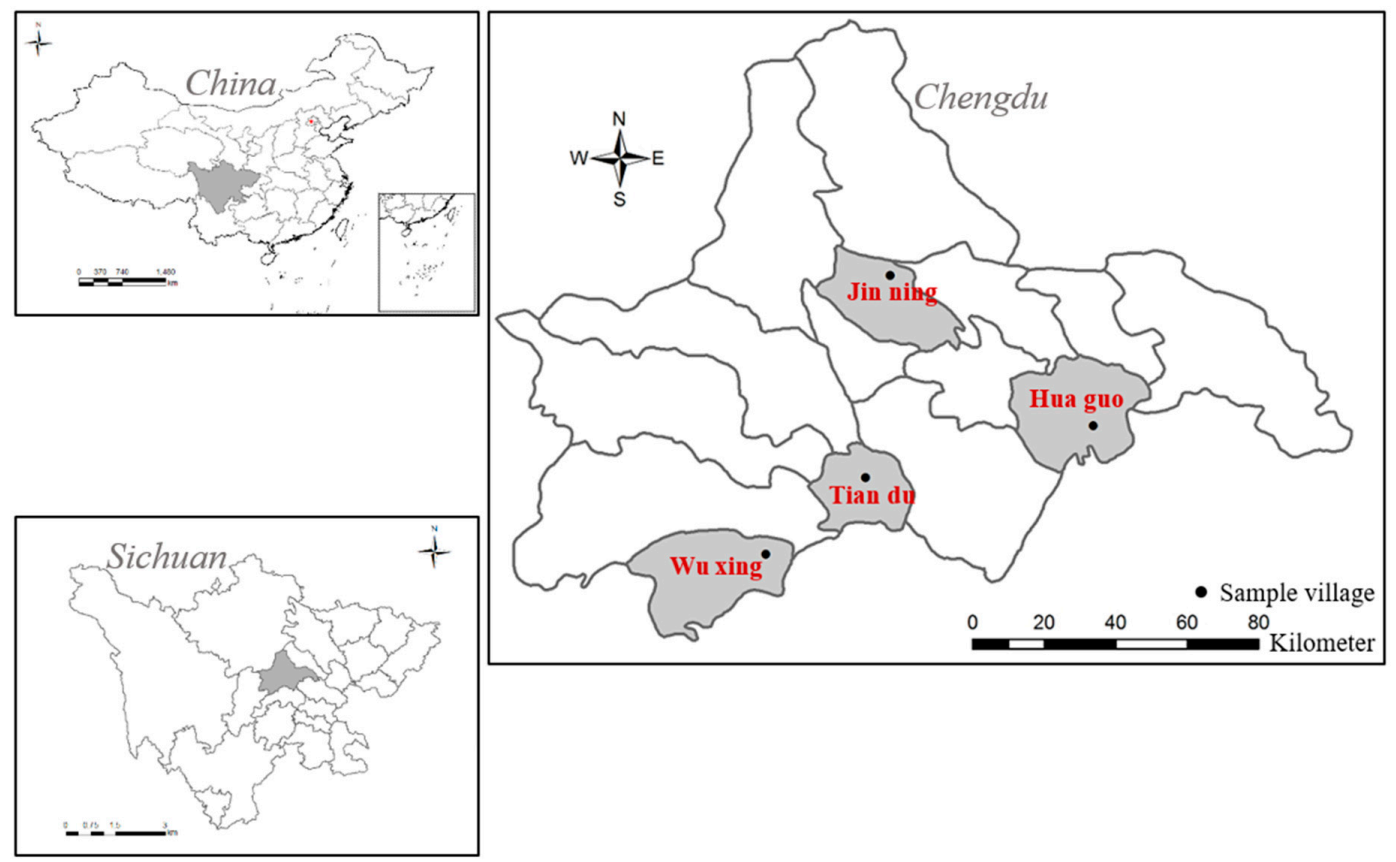

Figure 1. Location of the sample villages.

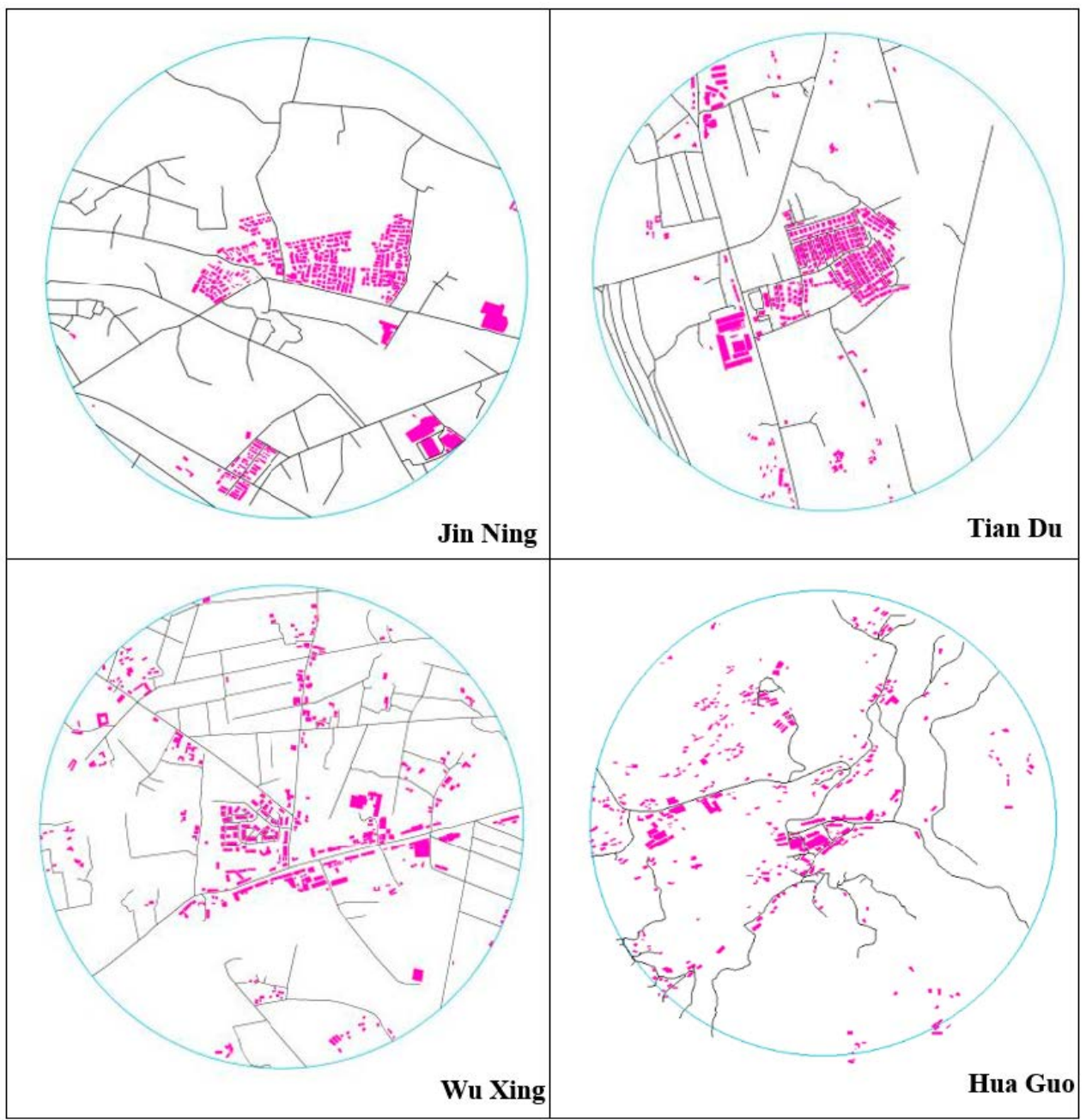

Figure 2. Study area of sample villages. 


\subsection{Data Collection}

\subsubsection{Questionnaires}

The questionnaire was refined after the preliminary investigation and field visit. It was mainly divided into four parts: socio-demographic factors, building characteristic factors, water conservation attitudes, and water conservation behavior. Except for the specific questions in the first part, all the other parts adopt multiple-choice questions.

(1) Socio-demographic factors. These factors mainly include the number of permanent residents, gender, age, annual income, and education level [50]. The basic information of the family and individual is an important part of the questionnaire survey. On this basis, we can understand the different backgrounds of the water-saving behavior of rural residents in Chengdu. Moreover, we can study the specific attitude of villagers with different levels of income and living environments to water-saving behavior.

(2) Building characteristic factors. These factors mainly include house size, building age, lighting and ventilation conditions, number of faucets and toilets, and the length of time for hot water to come out of the shower and kitchen. The water-saving behavior of residents is closely related to the structure, age, and size of houses [51]. Through the study of building information, we can determine the influence of various building characteristics on the water-saving behavior of villagers through the study of building information. Accordingly, building houses reasonably can effectively promote the water-saving behavior of residents.

(3) Water conservation attitudes. Specific questions involve personal attention to environmental issues, understanding of water resources, environmental control concept of water resources, and other attitudes and perception issues. Environmental attitude is initially considered a tendency of subjects to environmental behavior [52]. Therefore, this study mainly reflects the psychological tendency of the interviewees to save water through the expression and questions of water-saving-related attitude. This part contains 25 questions, and details of the measurement are presented in Table 5.

(4) Water conservation behavior. The water-saving behavior involves many indexes that are difficult to quantify. The use of water-saving appliances can greatly reduce the domestic water consumption of residents and play a good role in water saving; thus, it can be taken as a representative. A study in the United States, Australia, and the United Kingdom has shown that the water consumption of households equipped with water-saving appliances such as water-saving toilets, water-saving faucets, or low-flow showerheads has been reduced by $9 \%-12 \%$. If all of the existing household water equipment is replaced with efficient water-saving equipment, water consumption can be reduced by $35 \%-50 \%$ [53]. Geller and Erickson [54] found that water-saving appliances can significantly reduce water consumption. Roccaro and Falciglia [51] proposed that technical support has a significant effect on water saving, including installation of water meters and implementation and popularization of water-saving appliances. Therefore, using water-saving equipment is selected to represent water-saving behavior and works as the explanatory variable in this research.

From the above, all the main indicators of the questionnaire and their measurement can be shown in the following Table 1. 
Table 1. Variables and measurement.

\begin{tabular}{|c|c|}
\hline Variables & Measurement \\
\hline Gender & $1=$ Male $; 2=$ Female \\
\hline Age & $\begin{array}{c}1=0-18 \text { years old; } 2=19-45 \text { years old } ; 3=46-59 \text { years old } \\
4=60-74 \text { years old } ; 5=75 \text { years old or above }\end{array}$ \\
\hline $\begin{array}{l}\text { Education: highest degree of } \\
\text { the family }\end{array}$ & $\begin{array}{c}1=\text { no education; } 2=\text { primary school; } 3=\text { middle school; } \\
4=\text { high school (or vocational and technical secondary schools); } \\
5=\text { junior college (or higher vocational); } 6=\text { Bachelor degree or above }\end{array}$ \\
\hline Household size & $1=1 ; 2=2 ; 3=3 ; 4=4 ; 5=5 ; 6=6$ or above \\
\hline Household composition & $\begin{array}{c}1=\text { alone } ; 2=\text { couple } ; 3=\text { couple and older parents; } \\
4=\text { couple and their children; } 5=\text { three generations; } 6=\text { others }\end{array}$ \\
\hline Annual income per family & $1=0-20 \mathrm{~K} ; 2=20-40 \mathrm{~K} ; 3=40-60 \mathrm{~K} ; 4=60 \mathrm{~K}$ or above; \\
\hline Building age & $\begin{array}{c}1=0-2 \text { years; } 2=3-4 \text { years; } 3=5-6 \text { years; } 4=7-8 \text { years; } 5=8 \text { years } \\
\text { or above }\end{array}$ \\
\hline Size of the house & $\begin{aligned} 1= & 0-99 \mathrm{~m}^{2} ; 2=100-139 \mathrm{~m}^{2} ; 3=140-179 \mathrm{~m}^{2} \\
& 4=180-219 \mathrm{~m}^{2} ; 5=220 \mathrm{~m}^{2} \text { or above }\end{aligned}$ \\
\hline $\begin{array}{l}\text { Water heating time from the } \\
\text { shower or the kitchen }\end{array}$ & $1=0-15 \mathrm{~s} ; 2=15-30 \mathrm{~s} ; 3=30-45 \mathrm{~s} ; 4=45-60 \mathrm{~s} ; 5=60 \mathrm{~s}$ or above; \\
\hline Lighting and ventilation conditions & $1=$ very poor $; 2=$ poor $3=$ commonly $; 4=$ preferably $; 5=$ good \\
\hline No. of taps & $1=2$ or less $; 2=3 ; 3=4 ; 4=5 ; 5=6$ or above. \\
\hline No. of toilets & $1=1 ; 2=2 ; 3=3 ; 4=4 ; 5=5$ or above. \\
\hline 25 statements of & $1=$ Totally disagree $; 2=$ Quite disagree $3=$ Neutral $; 4=$ Quite agree; \\
\hline water-saving attitudes & $5=$ Totally agree \\
\hline Use of water-saving appliances & $0=$ no; $1=$ yes. \\
\hline
\end{tabular}

\subsubsection{Data Collection}

Data collection mainly went through two stages: pilot survey and formal questionnaire survey. The team conducted a pilot survey in January 2018. According to the pilot survey data, the validity of the questionnaire was verified, and the questionnaire was improved and modified. A formal survey was conducted in August 2018. In each village, two researchers formed a team. Considering that most villagers in China's rural areas have low education levels, they may not be able to understand the questionnaire correctly. Thus, this survey adopted one-to-one and face-to-face interviews. Moreover, our team contacted the village committee or the leader and sought their help to motivate the villagers before the questionnaire survey. In the sample villages, random sampling was adopted for the household survey. Rural households were randomly selected. If a selected rural household did not agree to participate in the survey, the researchers randomly turned to others. Each villager received a reward after completing the questionnaire. These measures helped increase the reliability of the questionnaire.

\subsubsection{Sample Component}

In this survey, 200 questionnaires were distributed, and 186 questionnaires were finally collected because the interviewees gave up answering during the survey. After double-checking, 21 invalid questionnaires were discarded, 165 valid questionnaires were obtained, and the effective sample rate was $82.5 \%$. Details are shown in Table 2. The final questionnaires consisted of the following: 39 in Jin Ning Village, accounting for 23.64\%; 50 in Tian Du Village, accounting for 30.30\%; 39 in Wu Xing community, accounting for $23.64 \%$; and 37 in Hua Guo Village, accounting for $22.42 \%$. The basic data show 621 households in Jin Ning Village, 1376 households in Tian Du Village, 554 households in Wu Xing community, and 781 households in Hua Guo Village. The proportions of households in the sample village are $6.28 \%, 3.63 \%, 7.04 \%$, and $4.74 \%$, respectively. Thus, the distribution of the questionnaires is reasonable and representative. 
Table 2. Sample component.

\begin{tabular}{ccccc}
\hline Villages & $\begin{array}{c}\text { Number of Efficient } \\
\text { Questionnaires }\end{array}$ & $\begin{array}{c}\text { Number of Households } \\
\text { to be Sampled }\end{array}$ & $\begin{array}{c}\text { Total } \\
\text { Households }\end{array}$ & Proportion \\
\hline Jin Ning & 39 & 24.03 & 621 & $6.28 \%$ \\
Tian Du & 50 & 24.55 & 1376 & $3.63 \%$ \\
Wu Xing & 39 & 23.92 & 554 & $7.04 \%$ \\
Hua Guo & 37 & 23.49 & 781 & $4.74 \%$ \\
\hline
\end{tabular}

\subsection{Descriptive Analysis}

\subsubsection{Socio-Demographic Variables}

In terms of socio-demographic factors, this study starts from two dimensions: individual and family. The statistical result of the original data is shown in Table 3. From the individual perspective, the number of women in this survey far exceeds that of men, accounting for $69.3 \%$ of the total mainly because most male villagers work outside or in farming, whereas most of the female villagers stay at home. In rural areas, women are often responsible for household living, laundry, and other work. Their water-saving behavior can represent the overall water-saving behavior of the family. The age distribution of the respondents is representative. Respondents who are over 75 years were strictly removed during data processing because respondents who are very much advanced in years may have problems with the questionnaire. The education level of the respondents is mainly junior high school, accounting for $43.6 \%$, followed by primary school and senior high school (or vocational high school, technical secondary school), accounting for $22.4 \%$ and $8.2 \%$, respectively. Respondents with an education level of junior high school (or vocational high school) and above are few. For individual annual income, distinguishing between individual and family income is not practical because most of the income of rural residents comes from the planting industry, which is run by the entire family. Thus, only the annual family income is considered.

Table 3. Socio-demographic factors.

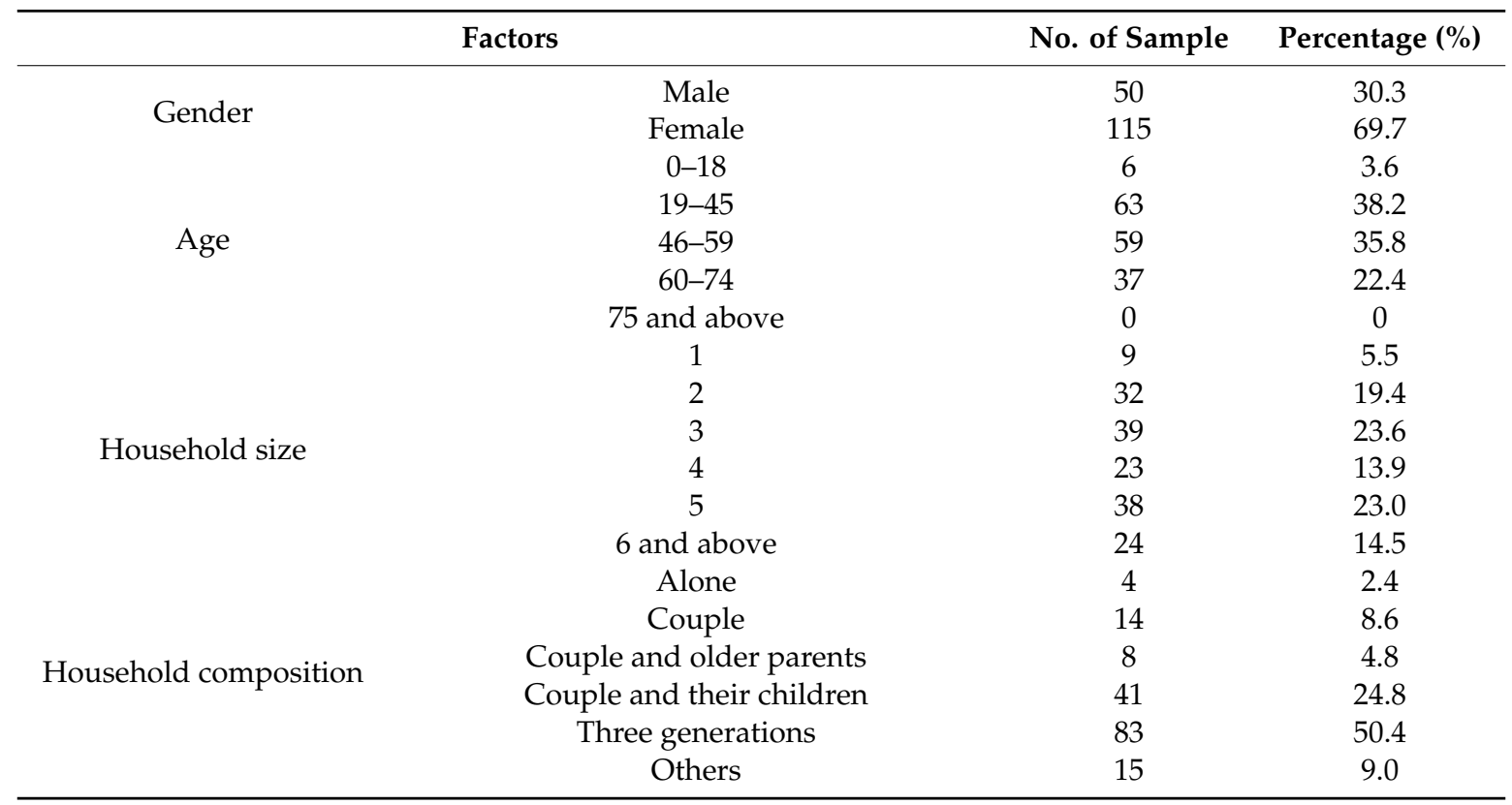


Table 3. Cont.

\begin{tabular}{cccc}
\hline & Factors & No. of Sample & Percentage (\%) \\
\hline \multirow{2}{*}{$\begin{array}{c}\text { Highest family } \\
\text { education background }\end{array}$} & No education & 1 & 0.6 \\
& Primary school & 6 & 3.6 \\
& Junior middle school & 36 & 21.8 \\
& High school (or vocational and technical & 55 & 33.3 \\
Junior college (or higher vocational) & 25 & 15.2 \\
Education background of & Bachelor degree or above & 42 & 25.5 \\
the interviewee & No education & 5 & 3.0 \\
& Pigh school (or vocational and technical & 37 & 22.4 \\
& secondary schools) & 72 & 43.6 \\
Annual family income & Junior college (or higher vocational) & 9 & 18.2 \\
& Bachelor degree or above & 12 & 5.5 \\
& 0-20K (20K not included) & 28 & 7.3 \\
& 20K-40K (40K not included) & 53 & 17.0 \\
\hline
\end{tabular}

The number of permanent family residents is mostly distributed in the range of $2-5$, accounting for $95 \%$. Most of the families surveyed are three generations living together, accounting for $50.3 \%$ of the total, followed by two couples living together with their children, accounting for $24.8 \%$; the proportion of couples living together with their parents or living alone is very small. The highest percentage of the educational level of family members is high school (or vocational high school, technical secondary school), followed by undergraduate and above, junior high school, junior college (or vocational high school), and primary schools.

\subsubsection{Building Characteristic Variables}

Building characteristics have a significant influence on water consumption. Thus, the questionnaire survey specifically investigates the information of the houses where the respondents live. Related variables include house size, house age, lighting, ventilation status, number of faucets and toilets, and the length of time for hot water to come out of the shower and kitchen. The preliminary analysis results are shown in Table 4 . The house size is mainly concentrated in 100-180 $\mathrm{m}^{2}$, accounting for $65.4 \%$. The house size of a few large families is much beyond the average level because many newly built houses in rural areas are distributed according to the number of registered permanent residences. The villages in this survey are newly built rural areas in recent years, with a house age of fewer than ten years. The water for the shower, washing dishes, and clothes is the most important and largest proportion of the villagers' domestic water consumption. A large amount of hot water is used in the shower or washing dishes. Generally, a large amount of water is wasted because the water heater is very far from the water outlet. According to the survey, the average time for hot water to flow out of the shower faucet varies: $41.2 \%$ takes more than $60 \mathrm{~s}$, and only $19.4 \%$ of the users can use hot water within $15 \mathrm{~s}$. The situation improves for the hot water usage in the kitchen: $22.4 \%$ of the users wait for more than $60 \mathrm{~s}$ when using hot water, and $29.7 \%$ of the users could use hot water within $15 \mathrm{~s}$. If we can reasonably plan during the construction of the house and control the distance between the kitchen, shower, and the position of the water heater, we can greatly reduce the waiting time for hot water and save water. Most of the rural houses are built by the residents themselves, so no high-rise buildings in the countryside block the sunlight. Thus, the villagers generally think that the lighting and ventilation conditions of the houses are good: $81.2 \%$ think that the lighting conditions are good or very good, and $84.9 \%$ think that the ventilation conditions are satisfying. 
Table 4. Building characteristics.

\begin{tabular}{cccccc}
\hline Parameter & \multicolumn{5}{c}{ Options and Proportions } \\
\hline \multirow{2}{*}{ House Size $\left(\mathrm{m}^{2}\right)$} & $0-99$ & $100-139$ & $140-179$ & $180-219$ & 220 and above \\
House Age & $9.1 \%$ & $29.1 \%$ & $36.3 \%$ & $14.0 \%$ & $11.5 \%$ \\
(years) & $0-2$ & $3-4$ & $5-6$ & $7-8$ & 8 and above \\
the time of hot water & $18.8 \%$ & $17.6 \%$ & $20.6 \%$ & $26.7 \%$ & $16.4 \%$ \\
out of the shower & Less than $15 \mathrm{~s}$ & $15-30 \mathrm{~s}$ & $30-45 \mathrm{~s}$ & $45-60 \mathrm{~s}$ & $60 \mathrm{~s}$ and above \\
the time of hot water & Less than $15 \mathrm{~s}$ & $15-30 \mathrm{~s}$ & $30-45 \mathrm{~s}$ & $45-60 \mathrm{~s}$ & $60 \mathrm{~s}$ and above \\
out of the kitchen & $29.7 \%$ & $21.8 \%$ & 10.3 & $15.8 \%$ & $22.4 \%$ \\
Lighting & Very poor & Poor & commonly & preferably & good \\
& $4.2 \%$ & $2.4 \%$ & $12.1 \%$ & $46.7 \%$ & $34.5 \%$ \\
Ventilation & Very poor & Poor & commonly & preferably & good \\
& $4.2 \%$ & $2.4 \%$ & $8.5 \%$ & $47.9 \%$ & $37 \%$ \\
Number of taps & $1-2$ & 3 & 4 & 5 & 6 and above \\
& $19.3 \%$ & $21.1 \%$ & $30.7 \%$ & $15.8 \%$ & $13.2 \%$ \\
Number of toilets & 1 & 2 & 3 & 4 & 5 and above \\
& $23.0 \%$ & $62.4 \%$ & $12.7 \%$ & $1.2 \%$ & $0.6 \%$ \\
\hline
\end{tabular}

\subsubsection{Water-Saving Attitudes Variables}

We can basically understand the respondents' water consumption behavior and various influencing factors through a descriptive analysis of water-saving attitude-related factors. Table 5 shows four attitudes with an average score of more than " 4 ," namely, $X_{6}, X_{8}, X_{14}$, and $X_{15}$. The standard deviation of these four indexes is less than 0.8 , which shows that the respondents have good values of respecting nature. Although the scores of the four influencing factors $X_{1}, X_{2}, X_{7}$, and $X_{16}$ decreased, their scores are all between 3.5-4 points, and their reflected ecological values are almost the same as those reflected by the previous factors. By contrast, the average scores of $X_{17}$ and $X_{18}$ are the lowest and less than 2.5 , whereas $\mathrm{X}_{25}$ only has 2.68 , which shows that the local farmers have a serious lack of awareness of water-saving equipment and a lack of publicity and education on water-saving equipment from the local government. The scores of $X_{5}, X_{9}, X_{11}, X_{12}, X_{13}$, and $X_{3}$ are also low, all between 2.5-3.0. These scores show that the local rural residents have certain limitations in the sense of moral responsibility for the environment. The local rural residents generally have good ecological values but often behave badly in terms of their interests. In addition, the scores of other remaining indicators such as $X_{21}, X_{22}, X_{23}$, and $\mathrm{X}_{24}$ are all around 3.5, which shows the herd mentality of rural residents; the positive water-saving behavior of others will promote their own water-saving behavior.

Table 5. Mean value of all water-saving attitude-related statements.

\begin{tabular}{|c|c|c|c|c|}
\hline Description & References & Mean & Median & $\begin{array}{l}\text { Standard } \\
\text { Deviation }\end{array}$ \\
\hline $\begin{array}{l}\text { I usually pay close attention to the water resources issues } \\
\text { reported by the media }\left(X_{1}\right)\end{array}$ & [52] & 3.54 & 4 & 1.186 \\
\hline I'm worried when I hear or see water-related issues $\left(X_{2}\right)$ & [52] & 3.73 & 4 & 1.081 \\
\hline $\begin{array}{l}\text { I take the action of saving water because of the laws and policies } \\
\text { made by the government }\left(\mathrm{X}_{3}\right)\end{array}$ & [52] & 2.7 & 3 & 1.104 \\
\hline $\begin{array}{l}\text { In order to save water and protect the environment, I am willing } \\
\text { to sacrifice my personal interests }\left(X_{4}\right)\end{array}$ & [52] & 3.26 & 3 & 1.088 \\
\hline $\begin{array}{l}\text { In order to save water and protect the environment, I'm ok to } \\
\text { offend some people if it is needed }\left(X_{5}\right)\end{array}$ & [52] & 2.91 & 3 & 1.198 \\
\hline $\begin{array}{l}\text { The problem of water resources is for the whole society, } \\
\text { and everyone is responsible for it }\left(X_{6}\right)\end{array}$ & [54] & 4.35 & 4 & 0.754 \\
\hline $\begin{array}{l}\text { As long as I am willing to do my best, I can improve or solve } \\
\text { certain environmental problems }\left(X_{7}\right)\end{array}$ & [52] & 3.93 & 4 & 0.989 \\
\hline If we take action, it will help to protect the environment $\left(\mathrm{X}_{8}\right)$ & [52] & 4.15 & 4 & 0.721 \\
\hline Ordinary people can also improve or solve water problems $\left(\mathrm{X}_{9}\right)$ & [54] & 2.87 & 3 & 1.265 \\
\hline
\end{tabular}


Table 5. Cont.

\begin{tabular}{|c|c|c|c|c|}
\hline Description & References & Mean & Median & $\begin{array}{l}\text { Standard } \\
\text { Deviation }\end{array}$ \\
\hline $\begin{array}{l}\text { Not only the powerful people can influence the improvement of } \\
\text { water resources }\left(\mathrm{X}_{10}\right)\end{array}$ & [54] & 3.1 & 3 & 1.310 \\
\hline $\begin{array}{l}\text { Compared with the comfort and convenience of life, I pay more } \\
\text { attention to water resources }\left(\mathrm{X}_{11}\right)\end{array}$ & [54] & 2.64 & 2 & 1.163 \\
\hline $\begin{array}{l}\text { I think saving water is more important than pursuing good } \\
\text { lifestyle and habits }\left(\mathrm{X}_{12}\right)\end{array}$ & [54] & 3.00 & 3 & 1.137 \\
\hline $\begin{array}{l}\text { Taking water-saving measures will not change my personal } \\
\text { lifestyle and habits }\left(\mathrm{X}_{13}\right)\end{array}$ & [54] & 2.71 & 3 & 1.153 \\
\hline Water resource is limited, so we must save water $\left(\mathrm{X}_{14}\right)$ & [54] & 4.34 & 4 & 0.790 \\
\hline We should respect nature and live in harmony with it $\left(\mathrm{X}_{15}\right)$ & [54] & 4.40 & 4 & 0.653 \\
\hline $\begin{array}{l}\text { Even for economic development, we cannot sacrifice the natural } \\
\text { environment }\left(\mathrm{X}_{16}\right)\end{array}$ & [52] & 3.61 & 4 & 1.342 \\
\hline $\begin{array}{l}\text { The water-saving equipment I want to buy is not much more } \\
\text { expensive than ordinary equipment }\left(\mathrm{X}_{17}\right)\end{array}$ & {$[51,53]$} & 2.49 & 2 & 1.085 \\
\hline $\begin{array}{l}\text { The technology of water-saving equipment is more mature } \\
\text { currently, and I can skillfully use it }\left(\mathrm{X}_{18}\right)\end{array}$ & {$[51,53]$} & 2.45 & 2 & 0.886 \\
\hline $\begin{array}{l}\text { I don't think it's very inconvenient for individuals to take } \\
\text { measures to save water }\left(\mathrm{X}_{19}\right)\end{array}$ & {$[51,53]$} & 3.30 & 3 & 1.217 \\
\hline$I^{\prime} m$ saving water because it helps me save money $\left(X_{20}\right)$ & author & 3.66 & 4 & 1.166 \\
\hline $\begin{array}{l}\text { I think the implementation of water-saving measures lacks } \\
\text { relevant publicity and education }\left(\mathrm{X}_{21}\right)\end{array}$ & [54] & 3.87 & 4 & 0.903 \\
\hline $\begin{array}{l}\text { Information from newspapers, TV and other media will affect } \\
\text { my decision of taking water-saving action }\left(X_{22}\right)\end{array}$ & {$[51,53]$} & 3.60 & 4 & 1.087 \\
\hline $\begin{array}{l}\text { My family, friends, etc. will affect my water-saving } \\
\text { behavior }\left(X_{23}\right)\end{array}$ & [54] & 3.39 & 4 & 1.056 \\
\hline $\begin{array}{l}\text { There are too few people around who pay attention to water } \\
\text { conservation, and I need more people to help and participate in } \\
\text { it }\left(\mathrm{X}_{24}\right)\end{array}$ & [54] & 3.96 & 4 & 0.851 \\
\hline $\begin{array}{l}\text { I usually pay attention to the use details of water } \\
\text { equipment }\left(X_{25}\right)\end{array}$ & {$[51,53]$} & 2.68 & 3 & 1.229 \\
\hline
\end{tabular}

\section{Results and Discussion}

\subsection{Exploratory Factor Analysis (EFA)}

EFA extracts the representative common factors from multiple variables. Its basic purpose is to use a few unrelated factors to describe the relationship between multiple variables and reduce information loss during transformation as much as possible [55]. First, the validity of "water-saving attitude-related factors" in the questionnaire was tested. The Cronbach's alpha value, which measures the internal consistency from 0 to 1 , is 0.620 . The larger the value, the better the consistency. A value larger than 0.6 indicates that the questionnaire is reliable [56]. Factor analysis results show that the Kaiser-Meyer-Olkin (KMO) measure of sampling adequacy index value is 0.740 , which reflects the relationship between simple correlation and partial correlation coefficient among variables. The larger the $\mathrm{KMO}$ value, the more common the factors among variables, the data are more suitable for factor analysis. Generally, the KMO value needs to be greater than 0.7 and significant. The KMO value shows common factors of the original matrix, and the data have a certain correlation; thus, the data are suitable for conducting EFA. In this study, the principal component method was used to extract the factor whose eigenvalue is greater than 1 . The final extraction factors total seven, and the total variance rate of interpretation is $62.034 \%$. The composition matrix after rotation is shown in Table 6. 
Table 6. Composition matrix after rotation.

\begin{tabular}{|c|c|c|c|c|c|c|c|}
\hline \multirow{2}{*}{ Variables } & \multicolumn{7}{|c|}{ Component } \\
\hline & 1 & 2 & 3 & 4 & 5 & 6 & 7 \\
\hline$X_{15}$ & 0.782 & -0.001 & 0.056 & -0.129 & -0.197 & 0.122 & 0.075 \\
\hline$x_{6}$ & 0.744 & 0.025 & 0.153 & -0.046 & 0.190 & 0.154 & -0.093 \\
\hline$X_{14}$ & 0.686 & 0.146 & 0.041 & -0.132 & 0.135 & 0.004 & 0.371 \\
\hline $\mathrm{X}_{8}$ & 0.555 & 0.490 & -0.129 & -0.019 & 0.046 & -0.057 & 0.084 \\
\hline$X_{16}$ & 0.456 & -0.083 & 0.238 & 0.303 & -0.395 & -0.253 & -0.170 \\
\hline$X_{4}$ & -0.114 & 0.776 & 0.024 & -0.041 & -0.100 & 0.314 & -0.101 \\
\hline$X_{5}$ & -0.103 & 0.736 & 0.102 & -0.122 & 0.106 & 0.312 & 0.043 \\
\hline$x_{2}$ & 0.262 & 0.593 & -0.131 & -0.174 & 0.099 & -0.053 & 0.064 \\
\hline$x_{1}$ & 0.115 & 0.490 & 0.000 & -0.067 & 0.438 & -0.001 & 0.073 \\
\hline$x_{7}$ & 0.405 & 0.474 & -0.073 & -0.092 & 0.263 & -0.212 & 0.039 \\
\hline$X_{11}$ & 0.083 & 0.002 & 0.842 & 0.035 & 0.020 & -0.064 & 0.053 \\
\hline$X_{9}$ & -0.095 & -0.222 & 0.661 & 0.119 & -0.133 & -0.035 & 0.143 \\
\hline$X_{12}$ & 0.229 & 0.132 & 0.615 & 0.345 & 0.001 & 0.264 & -0.224 \\
\hline $\mathrm{X}_{10}$ & 0.069 & 0.082 & 0.598 & 0.119 & -0.244 & -0.250 & 0.333 \\
\hline$X_{19}$ & 0.145 & 0.070 & 0.464 & 0.383 & -0.317 & -0.259 & -0.045 \\
\hline$X_{17}$ & -0.154 & 0.090 & 0.005 & 0.712 & -0.259 & -0.158 & 0.276 \\
\hline$x_{13}$ & -0.020 & -0.306 & 0.247 & 0.659 & 0.168 & 0.119 & -0.024 \\
\hline $\mathrm{X}_{18}$ & -0.249 & -0.247 & 0.132 & 0.641 & -0.080 & -0.074 & -0.003 \\
\hline$x_{25}$ & -0.403 & 0.185 & -0.158 & -0.414 & 0.181 & 0.104 & 0.176 \\
\hline$x_{23}$ & 0.003 & -0.031 & -0.180 & -0.033 & 0.813 & 0.050 & -0.074 \\
\hline$x_{22}$ & 0.068 & 0.427 & -0.038 & -0.120 & 0.670 & -0.018 & -0.045 \\
\hline$x_{21}$ & 0.262 & 0.203 & 0.032 & -0.184 & -0.021 & 0.694 & 0.076 \\
\hline$x_{3}$ & 0.088 & -0.112 & 0.442 & -0.075 & -0.095 & -0.648 & 0.036 \\
\hline$x_{20}$ & -0.003 & 0.054 & -0.259 & -0.140 & 0.141 & 0.051 & -0.678 \\
\hline$x_{24}$ & 0.363 & 0.170 & -0.089 & -0.111 & 0.197 & 0.358 & 0.602 \\
\hline Eigenvalues & 4.903 & 3.615 & 1.843 & 1.410 & 1.363 & 1.249 & 1.125 \\
\hline Proportion of variance explained (\%) & 11.908 & 11.101 & 10.558 & 8.378 & 8.142 & 6.582 & 5.366 \\
\hline Cumulative variance explained (\%) & 11.908 & 23.009 & 33.567 & 41.945 & 50.087 & 56.668 & 62.034 \\
\hline
\end{tabular}

According to the distribution of each factor, we obtained seven common facets, thus reducing 25 statements into seven factors, which are more representative.

$\mathrm{F} 1$ (environmental values) includes $\mathrm{X}_{6}, \mathrm{X}_{8}, \mathrm{X}_{14}, \mathrm{X}_{15}$, and $\mathrm{X}_{16}$. This factor can be regarded as a person's worldview that reflects his/her belief about the relationship of humankind with the natural world [3]. It shows how the residents care about the importance of the environment. This fundamental value determines the potential behavior he/she is going to take.

$F_{2}$ (self-responsibility) includes five indicators: $X_{1}, X_{2}, X_{4}, X_{5}$, and $X_{7}$. This factor reveals the residents' self-awareness and responsibility for the environment. Protecting the environment is not only paying more attention but needs real actions. This factor transfers the above-mentioned value into the individual's duty and responsibility.

$F_{3}$ (life habit and self-control) contains five statements: $X_{9}, X_{10}, X_{11}, X_{12}$, and $X_{19}$. The view of control is divided into external control and internal control. The group with the view of internal control thinks that its behavior can affect the current situation and change problems, or its behavior is meaningful and worth doing; external control holds the opposite view [57]. This factor shows the interviewees' perspective about lifestyle change and the intention to contribute to water conservation.

$\mathrm{F}_{4}$ (water conservation appliance) includes four indicators: $\mathrm{X}_{13}, \mathrm{X}_{17}, \mathrm{X}_{18}$, and $\mathrm{X}_{25}$, and represents the importance and the application of water conservation equipment. Carragher and Stewart [58] recorded average day diurnal water consumption patterns of 191 households in Australia and examined the different influence of water stock (e.g., taps, showerheads, and clothes washers) efficiency. Lee and Tansel [35] found that the implementation of water efficiency devices provides a positive synergistic effect on actual water savings. The use of water conservation equipment is one of the most 
observable, practical ways to save water, but the respondents do not usually pay attention to the use details of water equipment.

$\mathrm{F}_{5}$ (external incentives) includes $\mathrm{X}_{22}$ and $\mathrm{X}_{23}$. This factor can be interpreted as follows: external information, such as media publicity or the social norms, will influence the individual's choice of water conservation. Media campaigns have been verified effective, especially in the short run, in advocating people to save water [59]. Related research shows that people's behavior is semi-consciously selected to conform to social environments [19]; thus, the surrounding peer pressure will affect their own water conservation behavior. However, the negative factor loading $(-0.648)$ indicates no effective policy to pressure the energy conservation behavior of rural residents, which is consistent with item $21\left(X_{21}\right)$.

$\mathrm{F}_{6}$ (knowledge transfer) includes $\mathrm{X}_{3}$ and $\mathrm{X}_{21}$. Measurements of publicity, education, and policy requirement about water conservation can be summarized as the knowledge transfer [33]. It is verified to be an efficient way to provide information to raise environmental awareness and change attitudes and resource-consumption behavior [60]. This factor seems more effective in the short-term water conservation campaign. For a long-term effect, more feasible actions or instructions and repeated publicity can enhance efficiency [61].

$\mathrm{F}_{7}$ (money saving and co-participation) includes $\mathrm{X}_{20}$ and $\mathrm{X}_{24}$. This factor measures two different perspectives. One is the economic incentive in water conservation, which has been proven most efficient and direct for people considering taking water conservation action. Another can be interpreted as peer pressure. Peer comparison significantly influences human behavior. Based on a field experiment covering 3896 households in California, Bhanot [62] found that even peer rank about water usage has a different effect on higher- and lower-usage groups, but the comparison between peers helps motivate people to save water. The negative factor loading $(-0.678)$ indicates that the purpose of saving water for rural residents is not to save money.

\subsection{Multicollinearity of Variables}

Multicollinearity may cause low significance levels of various spatial variables [63]. Therefore, the multicollinearity of the independent variables must be studied. The variable expansion factor (VIF) was used to test for multicollinearity in this study. When the VIF value is high, a particular explanatory variable is likely to be represented by a linear function of other explanatory variables; thus, multicollinearity problems may occur in the model [64-66]. The VIF values of the explanatory variables are considerably low, as shown in Table 7, thereby indicating that no multicollinearity problem occurs.

Table 7. Multicollinearity Test.

\begin{tabular}{lccc}
\hline \multicolumn{1}{c}{ Variables } & Type & \multicolumn{2}{c}{ Collinearity Statistics } \\
& & Tolerance & VIF \\
\hline $\mathrm{F}_{1}$ (environmental values) & Common factor & 0.677 & 1.478 \\
$\mathrm{~F}_{2}$ (self-responsibility) & Common factor & 0.777 & 1.288 \\
$\mathrm{~F}_{3}$ (life habit and self-control) & Common factor & 0.834 & 1.199 \\
$\mathrm{~F}_{4}$ (water-saving appliance) & Common factor & 0.776 & 1.289 \\
$\mathrm{~F}_{5}$ (external incentives) & Common factor & 0.795 & 1.258 \\
$\mathrm{~F}_{6}$ (knowledge transfer) & Common factor & 0.758 & 1.319 \\
$\mathrm{~F}_{7}$ (money saving and co-participation) & Common factor & 0.689 & 1.452 \\
Household size & Ordinal & 0.624 & 1.603 \\
Household composition alone & Dummy & 0.654 & 1.53 \\
Couple & Dummy & 0.561 & 1.784 \\
Couple and older parents & Dummy & 0.744 & 1.343 \\
Couple and their children & Dummy & 0.681 & 1.469 \\
Three generations & Dummy & - & - \\
Others & Dummy & 0.795 & 1.257 \\
\hline
\end{tabular}


Table 7. Cont.

\begin{tabular}{llcc}
\hline \multicolumn{1}{c}{ Variables } & Type & \multicolumn{2}{c}{ Collinearity Statistics } \\
& & Tolerance & VIF \\
\hline Annual family income & & & \\
0-20K (20k not included) & Dummy & 0.636 & 1.571 \\
20-40K & Dummy & - & 1.782 \\
40-60K & Dummy & 0.561 & 1.837 \\
60k and above & Dummy & 0.544 & 2.35 \\
Gender & Dummy & 0.425 & 2.038 \\
Age & Dummy & 0.491 & - \\
0-18 & & - & 1.974 \\
19-45 & Dummy & 0.506 & 2.062 \\
46-59 & Dummy & 0.485 & 1.3 \\
60 and above & Dummy & 0.769 & 1.613 \\
Highest family education background & & \\
No education & Dummy & 0.62 & - \\
Primary school & & - & 1.619 \\
Junior middle school & Dummy & 0.618 & 1.346 \\
High school (vocational and technical secondary school & Dummy & Dummy & 1.605 \\
Junior college (higher vocational) & Dummy & 0.743 & 4.375 \\
Bachelor degree or above & Dummy & 0.623 & 4.327 \\
Water heating time from the shower & Ordinal & 0.229 & 2.613 \\
Water heating time from the kitchen & Ordinal & 0.231 & 2.563 \\
Lighting & Ordinal & 0.383 & 1.609 \\
Ventilation & Ordinal & 0.39 & 1.55 \\
House age & Ordinal & 0.622 & 1.939 \\
Number of taps & Ordinal & 0.645 & 0.615 \\
House size & Ordinal & 0.516 & \\
Number of toilets & Ordinal & & \\
\hline
\end{tabular}

\subsection{Binary Logistics Regression}

In this research, the dependent variable is whether rural residents select to buy water-saving appliances. It is a binary variable, and its value is either 1 or 0 . Thus, binary logistic regression analysis is used. The independent variables include socio-demographic factors, building characteristic factors, and water-saving attitude-related factors. In this model, the chi-square value for the Omnibus test is 145.771 and significant $(p<0.001)$. Moreover, the -2lnlikelihood value is 81.483 . The Cox \& Snell $\mathrm{R}^{2}$ and Nagelkerke $R^{2}$ are 0.589 and 0.785 , respectively, which indicate that the fitting degree of the model is good. At the same time, and the estimated results of the model are shown in Table 8.

Table 8. Result of binary logistic regression.

\begin{tabular}{lccc}
\hline \multicolumn{1}{c}{ Variables } & B & Wald & Sig. \\
\hline $\mathrm{F}_{1}$ (environmental values) & 3.207 & 25.872 & 0 \\
$\mathrm{~F}_{2}$ (self-responsibility) & -0.015 & 0.002 & 0.961 \\
$\mathrm{~F}_{3}$ (life habit and self-control) & 0.268 & 0.653 & 0.419 \\
$\mathrm{~F}_{4}$ (water-saving appliance) & 0.75 & 3.411 & 0.065 \\
$\mathrm{~F}_{5}$ (external incentives) & -0.607 & 2.774 & 0.096 \\
$\mathrm{~F}_{6}$ (knowledge transfer) & 0.162 & 0.279 & 0.598 \\
$\mathrm{~F}_{7}$ (money saving and co-participation) & 1.201 & 9.594 & 0.002 \\
\hline
\end{tabular}


Table 8. Cont.

\begin{tabular}{lccc}
\hline \multicolumn{1}{c}{ Variables } & B & Wald & Sig. \\
\hline Household size & -0.619 & 3.911 & 0.048 \\
Household composition & -2.695 & 0.944 & 0.331 \\
Alone & -1.276 & 0.599 & 0.439 \\
Couple & -1.595 & 0.541 & 0.462 \\
Couple and older parents & -1.227 & 1.807 & 0.179 \\
Couple and their children & - & - & - \\
Three generations & -3.12 & 5.704 & 0.017 \\
Others & 0.867 & 0.611 & 0.435 \\
Annual family income & - & - & - \\
0-20K (20k not included) & -0.863 & 0.797 & 0.372 \\
20-40K & 0.722 & 0.572 & 0.449 \\
40-60K & 17.162 & 0 & 0.999 \\
60k and above & - & - & - \\
Age & 1.1 & 1.52 & 0.218 \\
0-18 & 0.194 & 0.037 & 0.848 \\
19-45 & 0.007 & 0.0226 & 0.0897 \\
46-59 & & & \\
60 and above & & & \\
Gender & 0.356 & 0.024 & 0.877 \\
Highest family education background & -2.237 & 4.646 & 0.031 \\
No education & - & - & - \\
Primary school & -0.283 & 0.071 & 0.789 \\
Junior middle school & 2.281 & 2.798 & 0.094 \\
High school (vocational and technical secondary school & 1.309 & 0.943 & 0.332 \\
Junior college (higher vocational) & 1.503 & 11.93 & 0.001 \\
Bachelor degree or above & 0.905 & 4.724 & 0.03 \\
Water heating time from the shower & -1.236 & 5.133 & 0.023 \\
Water heating time from the kitchen & 0.454 & 0.737 & 0.391 \\
Lighting & 0.649 & 4.437 & 0.035 \\
Ventilation & -0.306 & 1.163 & 0.281 \\
House age & 0.01 & 0.001 & 0.975 \\
Number of taps & 0.192 & 0.097 & 0.755 \\
House size & 1.774 & 0.268 & 0.605 \\
Number of toilets & & & \\
Constant & & & \\
\hline & & & \\
\hline
\end{tabular}

\subsection{Discussion}

According to the significance of the influencing factors in Table 8, there are several factors related to the water-saving behavior in rural China.

$\mathrm{F}_{1}$ (environmental values) has the most significant effect on whether residents buy water-saving appliances. This factor passed the $1 \%$ significance test and has a positive role in promoting rural residents to adopt water-saving behavior, indicating that groups with a correct understanding of environmental values are more willing to buy water-saving appliances mainly because individual behavior is affected by his/her own consciousness. Thus, different environmental values will lead to different water-use and water-saving behaviors. The research of Corral-Verdugo and Bechtel [38] also confirmed that the water consumption of a group with a strong environmental awareness is often lower than that of a group with a weak environmental awareness, and a group with the view that "water resources are inexhaustible" will consume more water than other groups.

$\mathrm{F}_{4}$ (water-saving appliance) has a significant positive influence on water-saving behavior. The components of $\mathrm{F}_{4}$ are "Taking water-saving measures will not change my personal lifestyle and habits," "The water-saving equipment I want to buy is not much more expensive than ordinary equipment," "The technology of water-saving equipment is more mature currently, and I can skillfully use it," "I usually pay attention to the use details of water equipment." The more mature the 
water-saving appliances, the less expensive they are, the less they change people's habits, the more people are willing to use water-saving appliances. People's attention to water-saving appliances can also lead them to use water-saving appliances. This conclusion is easy to understand and consistent with existing research results $[51,54]$.

$\mathrm{F}_{5}$ (external incentives) has a significant negative effect on water-saving behavior, which is extracted from the information of "Information from newspapers, TV, and other media will affect my decision of taking water-saving action," and "My family, friends, etc. will affect my water-saving behavior." This result shows that the external interference of water-saving behavior is not conducive to the residents' taking water-saving measures. It also shows that the public does not have a unified view on adopting water-saving behavior, and the positive effect of adopting water-saving measures is weak. Therefore, the national water saving also needs more effective policy guidance, popularization, and publicity [54].

$\mathrm{F}_{7}$ (money saving and co-participation), which also passed the $1 \%$ significance test, has a positive effect on residents' purchase of water-saving appliances. Residents who hold the two views of "I take water-saving action because I can save money" and "There are too few people around who pay attention to water-saving, I need more people to help and participate together" are more willing to install water-saving appliances. The statement, "The reason why I adopt water-saving behavior is that I can save money," shows that economic cost plays an important role in the water-saving behavior of residents. Residents who hold the view, "There are too few people around who pay attention to water-saving, and I need more people to help and participate together" are more willing to buy water-saving devices, indicating that such groups have a certain sense of collectivism, which is also related to the social background of traditional human society in rural China.

Household population information influences the water-saving behavior of respondents. First, the size of the family population significantly negatively affects the water-saving behavior of the respondent because the water-use behavior or habits of family members has a direct effect on the respondents, and national water-saving consciousness is not good at present (as discussed above). The more educated the residents are, the more willing they are to conduct water-saving behavior, mainly because more educated residents are more likely to have the correct environmental outlook and awareness of water and water conservation. Considerable literature studies have shown that groups with a high education level will have a strong awareness of water and energy conservation $[3,50]$.

Water heating time from the shower or the kitchen also motivates the residents to buy water-saving devices. The longer the time to produce hot water, the greater the amount of water wasted. This may promote the residents to take more active action to save water. This phenomenon also shows that the residents are subconsciously not willing to waste water. The waste of water resources will increase the water cost, which will promote the residents' awareness of water conservation to a certain extent. When building houses in the future, we can re-organize the distance between the water heater and toilet and kitchen faucet because a reasonable arrangement can effectively reduce water consumption. House age also has a certain role in promoting the purchase of water-saving appliances. The older the building is, the stronger the willingness of residents to purchase water-saving appliances. This finding is due to the rather low construction quality of the buildings in rural areas compared with those in urban areas. Those built environment factors shed light on future house construction.

\section{Conclusions and Suggestions}

Based on existing literature and empirical analysis, 165 questionnaires were collected from four rural areas around Chengdu by face-to-face questionnaire surveys. This study further used descriptive statistics, EFA, and the binary logistic regression model to analyze the water-saving behavior of rural residents interviewed. The main influencing factors of the water-saving behavior of rural residents in Chengdu were systematically analyzed. The main conclusions and suggestions are as follows.

For socio-demographic factors, the variable "education of the interviewee" is significantly positively related to water conservation behavior, while the household size significantly negatively 
affects water conservation behavior. This finding is consistent with other studies, indicating that people with a high level of education are more likely to have a correct environmental perspective and awareness of water and water conservation, and national water-saving consciousness is not good at present. During the site interview, we also found that the major responders are female. They are the main forces for daily water use. Thus, targeted education to those female residents will increase the effect and have a better influence on water conservation behavior.

For building characteristic factors, house age and the installation of certain appliances affect the way the residents adopt water conservation behavior. The older the house is, the larger the possibility that the residents will install water-saving appliances. Several appliances affect the residents' water conservation behavior as well, especially the water heater. The longer the time to produce hot water from the kitchen or toilet, the higher the tendency of residents to take water-saving action because they can reduce water consumption and save money. The economic concern is quite important in their daily life. Thus, the local government can make a more suitable arrangement or design of the new communities in rural areas. Better design, namely shortening the distance between the water heater and the taps, would help save water. More education or publicity about water-saving appliances can be promoted in rural areas. The building age is usually larger for those who are not moving to a newly constructed community. Good advertisement could increase their desire to install water-saving appliances.

For water conservation attitude, EFA was used to extract seven common factors from the original 25 statements related to water conservation attitudes. Binary logistic regression shows that $\mathrm{F}_{1}$ (environmental values), $\mathrm{F}_{4}$ (water-saving appliance), $\mathrm{F}_{5}$ (external incentives), and $\mathrm{F}_{7}$ (money saving and co-participation) are the most influential factors. For $F_{1}$, different environmental values lead to different water-use and water-saving behaviors. When respondents value the importance of the environment, they would take more active actions to save water and protect the environment. For $\mathrm{F}_{4}$, the regularization and popularization of water-saving facilities can promote residents to adopt water-saving behaviors. Residents' attention to water-saving facilities will encourage more water-saving behavior. For $\mathrm{F}_{5}$, external incentives such as media information and family members' water-saving behaviors significantly negatively affect the interviewees' water-saving behaviors, mainly because the social popularization of water-saving behaviors is not sufficient. For $F_{7}$, economic concern plays an important role in determining water use. Therefore, the local government should either invest more in education or subsidize the residents to buy or install water-saving appliances. Saving water by changing water-use habits is very difficult, and the most effective way is to use water-saving instruments. Therefore, the first step is to promote water-saving appliances and encourage villagers to install them. Second, the local government should teach the villagers how to use those appliances effectively.

Generally, most rural residents demonstrate an incorrect perception of water resource: the water resource is endless and can be (re)used at will. Moreover, the degree of taking water-saving behavior among residents is not high, and only a few residents will recycle the wastewater. The proportion of those who purchase water-saving appliances is relatively low, and many residents are not sure whether the appliances they bought are truly water-saving. Even if they have installed water conservation equipment, they may be confused about how to use it. Thus, promoting the importance of water resources is urgently demanded to raise their consciousness through media campaigns (television, radio, or internet), specific talks, and leaflet distribution. However, the villagers' trust in grass-root government departments is much higher than that in other channels. Thus, we should focus on this channel as an efficient medium to strengthen the education of water-saving awareness of villagers.

Enlightened by other literature, knowledge transfer such as education and publicity may have a strong effect in the short run [61]. Repeated information distribution is needed to enhance the effect on water conservation in the long run. Related research suggests that most households are initially motivated to save water but fail to turn it into real water conservation action. Thus, the local government can take more practical strategies to help the residents maintain the behavior, such as subsidizing the adoption of water conservation appliances, providing door-to-door guidance of the 
use of the equipment, and holding regular training. These practical, feasible actions would increase the residents' self-efficacy to maintain water conservation habits.

Admittedly, this research is far from perfect and suffers from two distinct shortcomings: (1) generalization or transferability of the results and (2) limited sample size. Field trips in rural China are difficult in the way of transportation and communication with villagers. The research team made great efforts to enlarge the sample pool. In future research, one possible direction is to link the survey data with census data, such as the China Household Finance Survey. Another extension is to run a set of field experiments to compare the adoption of water-saving facilities.

Author Contributions: All authors contributed to the research presented in this paper. Y.L., Y.W., and Y.A. had the original idea for the study; the co-authors conceived and designed the questionnaire. Y.A. and Y.W. organized the investigation; H.Z. analyzed the data and drafted the manuscript, which was revised by Y.L., L.Y. and Y.A. All authors have read and agreed to the published version of the manuscript.

Funding: The authors appreciate financial support from the Humanities and Social Sciences Research Fund of the Ministry of Education of China (No. 18YJC630105), Social Science Fund of Chengdu (No. 2019R11), Sichuan Province Social Science Planning project (SC19TJ030), Sichuan science and technology department soft science major work support research project (20RKX0412/ 2020JDR0177). Sichuan Rural Community Governance Research Center funding (SQZL2019C01), Sichuan Xinnong Village Wind Civilization Construction Research Center funding (SCXN2019-004), the Natural Science Key Project from the Sichuan Provincial Department of Education (18ZA0048), and the Development Research Center of Oil and Gas, Sichuan (CYQK-SKB17-04).

Conflicts of Interest: The authors declare no conflict of interest.

\section{References}

1. Liu, Y.; Hu, X.; Zhang, Q.; Zheng, M. Improving Agricultural Water Use Efficiency: A Quantitative Study of Zhangye City Using the Static CGE Model with a CES Water-Land Resources Account. Sustainability 2017, 9, 308. [CrossRef]

2. Domene, E.; Saurí, D. Urbanisation and water consumption: Influencing factors in the metropolitan region of Barcelona. Urban Stud. 2006, 43, 1605-1623. [CrossRef]

3. Russell, S.V.; Fielding, K.S. Water demand management research: A psychological perspective. Water Resour. Res. 2010, 46, 43-63.

4. China Statistical Yearbook. 2019. Available online: http://www.stats.gov.cn/tjsj/ndsj/2019/indexch.htm (accessed on 1 May 2020).

5. Qiu, J. Safeguarding China's water resources. Natl. Sci. Rev. 2018, 5, 102-107. [CrossRef]

6. Qian, Z.Y.; Lin, B.N.; Zhang, W.Z.; Sun, X.T. Comprehensive Report of Strategy on Water Resources for China's Sustainable Development; China Water and Hydropower Press: Beijing, China, 2002.

7. Liu, B.; Speed, R. Water resources management in the People's Republic of China. Water Res. Dev. 2009, 25, 193-208. [CrossRef]

8. Cho, R. How China is dealing with its water crisis. Blogs from the Earth Institute State of the Planet. 2011. Available online: https://blogs.ei.columbia.edu/2011/05/05/how-china-is-dealing-with-its-water-crisis/ (accessed on 2 May 2020).

9. Hamilton, L.C. Saving water: A causal model of household conservation. Sociol. Perspect. 1983, 26, 355-374. [CrossRef]

10. Cheng, H.; Hu, Y.; Zhao, J. Meeting China's water shortage crisis: Current practices and challenges. Environ. Sci. Technol. 2009, 43, 240-244. [CrossRef]

11. Dolnicar, S.; Hurlimann, A.; Grün, B. Water conservation behavior in Australia. J. Environ. Manag. 2012, 105, 44-52. [CrossRef]

12. Worthington, A.C.; Hoffman, M. An empirical survey of residential water demand modelling. J. Econ. Surv. 2008, 22, 842-871.

13. Aprile, M.C.; Fiorillo, D. Water conservation behavior and environmental concerns: Evidence from a representative sample of Italian individuals. J. Clean. Prod. 2017, 159, 119-129. [CrossRef]

14. Moore, S.; Murphy, M.; Watson, R. A longitudinal study of domestic water conservation behavior. Popul. Environ. 1994, 16, 175-189. [CrossRef] 
15. Zhang, H.; Dong, J.; Yan, J. Review on the driving force of urban water use change. Acta Agric. Jiangxi 2009, 11, 195-199.

16. Wang, Y.; Feng, L.; Zhao, D.; Mao, D. Relational analysis of influence factors on residential water consumption in Jinhua City. J. Water Res. Water Eng. 2011, 3, 53-56.

17. Li, M. Analysis about Present Situation of Rural Domestic Water and Influential Factors of Water Consumption: Based on Household Survey in Shuyang, Jiangsu Province; Nanjing Agricultural University: Nanjing, China, 2011.

18. Zhu, L.; Gong, H.; Li, X.; Wang, R.; Chen, B.; Dai, Z.; Teatini, P. Land subsidence due to groundwater withdrawal in the northern Beijing plain, China. Eng. Geol. 2015, 193, 243-255. [CrossRef]

19. Otaki, Y.; Ueda, K.; Sakura, O. Effects of feedback about community water consumption on residential water conservation. J. Clean. Prod. 2017, 143, 719-730. [CrossRef]

20. Jiang, W.; Huang, C.; Liu, Q.; Liu, Y.; Tian, S. Investigation on current situation of water consumption and water quota. Chongqing Water Wastewater Eng. 2019, 55, 103-107.

21. Lam, S.-P. Predicting intention to save water: Theory of planned behavior, response efficacy, vulnerability, and perceived efficiency of alternative solutions. J. Appl. Soc. Psychol. 2006, 36, 2803-2824. [CrossRef]

22. Fan, L. Study of Domestic Water Use Behaviors in Rural Households: Insights from Shannxi Plain, the Wei River Basin, China; Northwest A\&F University: Xianyang, China, 2014.

23. Nauges, C.; Thomas, A. Privately operated water utilities, municipal price negotiation, and estimation of residential water demand: The case of France. Land Econ. 2000, 76, 68-85. [CrossRef]

24. Zhao, H.; Zhong, Q.; Ao, Y. Analysis on the influencing factors of water saving behavior of residents in rural areas of Sichuan Province. Rural Econ. Sci. Technol. 2019, 30, 33-34.

25. Yan, L.; McManus, P.; Duncan, E. Understanding ethnic differences in perceptions, attitudes, and behaviours: A study of domestic water use in Sydney. Geogr. Res. 2017, 56, 54-67. [CrossRef]

26. Andersen, B.J. Residential Landscape Water Use and Conversation; University of Idaho: Idahao, China, 2008.

27. Tong, Y.; Fan, L.; Niu, H. Water conservation awareness and practices in households receiving improved water supply: A gender-based analysis. J. Clean. Prod. 2017, 141, 947-955. [CrossRef]

28. Höglund, L. Household demand for water in Sweden with implications of a potential tax on water use. Water Resour. Res. 1999, 35, 3853-3863. [CrossRef]

29. Chen, X.; Xu, J.; Ji, Y. Research on determinant factors in residential water demand. J. Econ. Water Res. 2005, 23, 23-24.

30. Conner, M.; Armitage, C.J. Extending the theory of planned behavior: A review and avenues for further research. J. Appl. Soc. Psychol. 1998, 28, 1429-1464. [CrossRef]

31. Cook, S.W.; Berrenberg, J.L. Approaches to encouraging conservation behavior: A review and conceptual framework. J. Soc. Issues 1981, 37, 73-107. [CrossRef]

32. Ajzen, I.; Joyce, N.; Sheikh, S.; Cote, N.G. Knowledge and the prediction of behavior: The role of information accuracy in the theory of planned behavior. Basic Appl. Soc. Psychol. 2011, 33, 101-117. [CrossRef]

33. Koop, S.H.; Van Dorssen, A.; Brouwer, S. Enhancing domestic water conservation behaviour: A review of empirical studies on influencing tactics. J. Environ. Manag. 2019, 247, 867-876. [CrossRef]

34. Ajzen, I.; Fishbein, M. Attitudes and the attitude-behavior relation: Reasoned and automatic processes. Eur. Rev. Soc. Psychol. 2000, 11,1-33. [CrossRef]

35. Lee, M.; Tansel, B. Water conservation quantities vs customer opinion and satisfaction with water efficient appliances in Miami, Florida. J. Environ. Manag. 2013, 128, 683-689. [CrossRef]

36. Chaudhary, A.K.; Lamm, A.J.; Warner, L.A. Using cognitive dissonance to theoretically explain water conservation intentions. J. Agric. Educ. 2018, 59, 194-210. [CrossRef]

37. Chaudhary, A.K.; Warner, L.A.; Lamm, A.J.; Israel, G.; Rumble, J.; Cantrell, R. Using the theory of planned behavior to encourage water conservation among extension clients. J. Agric. Educ. 2017, 58, 185-202. [CrossRef]

38. Corral-Verdugo, V.; Bechtel, R.B.; Fraijo-Sing, B. Environmental beliefs and water conservation: An empirical study. J. Environ. Psychol. 2003, 23, 247-257. [CrossRef]

39. Clark, W.A.; Finley, J.C. Determinants of water conservation intention in Blagoevgrad, Bulgaria. Soc. Nat. Resour. 2007, 20, 613-627. [CrossRef]

40. Willis, R.M.; Stewart, R.; Panuwatwanich, K.; Williams, P.R.; Hollingsworth, A.L. Quantifying the influence of environmental and water conservation attitudes on household end use water consumption. J. Environ. Manag. 2011, 92, 1996-2009. [CrossRef] [PubMed] 
41. Ma, X.; Wu, D.; Zhang, S. Multiple Goals Dilemma of Residential Water Pricing Policy Reform: Increasing Block Tariffs or a Uniform Tariff with Rebate? Sustainability 2018, 10, 3526. [CrossRef]

42. Nieswiadomy, M.L.; Molina, D.J. A note on price perception in water demand models. Land Econ. 1991, 67, 352-359. [CrossRef]

43. Hu, F. Study on the Influencing Factors of Domestic Water Demand of Urban Residents: A Case Study of Nantong City; Zhejiang University: Hangzhou, China, 2006.

44. Mu, Q.; Zhang, S.; Ma, X. Driving factors of household adoption of water conservation behaviors. Acta Sci. Nat. Univ. Pekin. 2014, 50, 587-594.

45. Chang, G. Factors influencing water conservation behavior among urban residents in China's arid areas. Water Policy 2013, 15, 691-704. [CrossRef]

46. Renwick, M.E.; Archibald, S.O. Demand side management policies for residential water use: Who bears the conservation burden? Land Econ. 1998, 74, 343-359. [CrossRef]

47. Chaudhary, A.K.; Warner, L.A.; Ali, A.D. Using perceived benefits to segment residential landscape irrigation users. Urban For. Urban Green. 2019, 38, 318-329. [CrossRef]

48. Huang, X.; Huang, Z.; Zhang, L.; Zhou, X.; Liu, S. The effect of block-rate water price policy on residential water consumption time series. China Popul. Res. Environ. 2017, 27, 108-111.

49. Xiong, S. Empirical analysis of influencing factors of urban residents' domestic water: Chengdu city as an example. Sci. Technol. Ind. 2018, 1, 92-97.

50. Willis, R.M.; Stewart, R.; Giurco, D.P.; Talebpour, M.R.; Mousavinejad, A. End use water consumption in households: Impact of socio-demographic factors and efficient devices. J. Clean. Prod. 2013, 60, 107-115. [CrossRef]

51. Roccaro, P.; Falciglia, P.P.; Vagliasindi, F.G.A. Effectiveness of water saving devices and educational programs in urban buildings. Water Sci. Technol. 2011, 63, 1357-1365. [CrossRef]

52. Polonsky, M.J.; Vocino, A.; Grimmer, M.; Miles, M.P. The interrelationship between temporal and environmental orientation and pro-environmental consumer behaviour. Int. J. Consum. Stud. 2014, 38, 612-619. [CrossRef]

53. Inman, D.; Jeffrey, P. A review of residential water conservation tool performance and influences on implementation effectiveness. Urban Water J. 2006, 3, 127-143. [CrossRef]

54. Geller, E.S.; Erickson, J.B.; Buttram, B.A. Attempts to promote residential water conservation with educational, behavioral and engineering strategies. Popul. Environ. 1983, 6, 96-112. [CrossRef]

55. Zhao, R.; Zhan, L.; Yao, M.; Yang, L. A geographically weighted regression model augmented by Geodetector analysis and principal component analysis for the spatial distribution of PM2.5. Sust. Cities Soc. 2020, 56, 102106. [CrossRef]

56. Lai, K.-H.; Ngai, E.W.; Cheng, T. Measures for evaluating supply chain performance in transport logistics. Transp. Res. Part E Logist. Transp. Rev. 2002, 38, 439-456. [CrossRef]

57. Sun, Y. Study on Residents' Environmental Behavior and Its Influencing Factors; Dalian University of Technology: Dalian, China, 2006.

58. Carragher, B.J.; Stewart, R.; BealiD, C. Quantifying the influence of residential water appliance efficiency on average day diurnal demand patterns at an end use level: A precursor to optimised water service infrastructure planning. Resour. Conserv. Recycl. 2012, 62, 81-90. [CrossRef]

59. Kneebone, S.; Fielding, K.S.; Smith, L.D. It's what you do and where you do it: Perceived similarity in household water saving behaviours. J. Environ. Psychol. 2018, 55, 1-10. [CrossRef]

60. Fielding, K.S.; Spinks, A.; Russell, S.V.; McCrea, R.; Stewart, R.; Gardner, J. An experimental test of voluntary strategies to promote urban water demand management. J. Environ. Manag. 2013, 114, 343-351. [CrossRef] [PubMed]

61. Syme, G.J.; Nancarrow, B.E.; Seligman, C. The evaluation of information campaigns to promote voluntary household water conservation. Eval. Rev. 2000, 24, 539-578. [CrossRef]

62. Bhanot, S.P. Rank and response: A field experiment on peer information and water use behavior. J. Econ. Psychol. 2017, 62, 155-172. [CrossRef]

63. Ding, C.; Wang, D.; Liu, C.; Zhang, Y.; Yang, J. Exploring the influence of built environment on travel mode choice considering the mediating effects of car ownership and travel distance. Transp. Res. Part A-Policy Prac. 2017, 100, 65-80. [CrossRef] 
64. Yang, L.; Zhou, J.; Shyr, O.F.; Huo, D.D. Does bus accessibility affect property prices? Cities 2019, 84, 56-65. [CrossRef]

65. Yang, L.; Chau, K.W.; Szeto, W.Y.; Cui, X.; Wang, X. Accessibility to transit, by transit, and property prices: Spatially varying relationships. Transp. Res. Part D-Transp. Environ. 2020, 85, 102387. [CrossRef]

66. Yang, L.; Chu, X.; Gou, Z.; Yang, H.; Lu, Y.; Huang, W. Accessibility and proximity effects of bus rapid transit on housing prices: Heterogeneity across price quantiles and space. J. Transp. Geogr. 2020, 88, 102850. [CrossRef]

(C) 2020 by the authors. Licensee MDPI, Basel, Switzerland. This article is an open access article distributed under the terms and conditions of the Creative Commons Attribution (CC BY) license (http://creativecommons.org/licenses/by/4.0/). 